\title{
Representasi Budaya Patriarki dalam Film Istri Orang
}

\author{
Titin Setiawati ${ }^{1}$ \\ ${ }^{1}$ Ilmu Komunikasi FISIP UHAMKA \\ *Email korespodensi: titi.setiwati@uhamka.ac.id
}

Kata kunci: Representasi, Patriarki, Film

Keyword: Representation, Patriarchy, Film

\section{A B S T R A K}

Patriarki pada dasarnya adalah kekuasaaan laki-laki, dimana patriarki ini menyebabkan ketimpangan dalam relasi antara laki-laki dan perempuan. Patriarki menyebabkan posisi perempuan berada di bawah posisi laki-laki. Budaya patriarki ada dalam kehidupan sehari-hari dalam masyarakat. Dan sering tergambar dalam media massa, termasuk juga dalam film. Penelitian ini ingin membongkar bagaimana budaya patriarki yang terjadi dalam masyarakat direpresentasikan. Teori yang digunakan adalah semiotika Roland Barthes dan bidang kehidupan yang berada dalam kontrol patriarki. Metode yang digunakan adalah kualitatif deskriptif. Hasil penelitian ini menunjukkan bahwa film Istri Orang merepresentasikan patriarki dalam 5 bidang, yaitu daya produktif atau tenaga kerja perempuan, reproduksi perempuan, kontrol atas seksualitas perempuan, dan harta milik \& sumber daya ekonomi

\section{A B S T R A C T}

Patriarchy is basically the authority of men, where patriarchy causes inequality in relations between men and women. Patriarchy causes women's position below the position of men. This patriarchal culture exists in everyday life in society. And often portrayed in the mass media, including in film. This study wants to discover how the patriarchal culture that occurs in society is represented. The theory used is Roland Barthes's semiotics and the field of life which is under patriarchal control. The method used is descriptive qualitative. The results of this study indicate that the Istri Orang film represents patriarchy in 5 fields ; the productive power or women labor, female reproduction, control over female sexuality, and property \& other economic resources

\section{PENDAHULUAN}

Perkembangan teknologi yang begitu pesat saat ini, bidang komunikasi juga mengalami perkembangan yang sangat pesat. Manusia berkomunikasi tak hanya menggunakan indera yang dimiliki, tetapi juga menggunakan berbagai alat dan hasil teknologi yang dapat mendukung kegiatan tersebut. Sehingga kemudian melahirkan aktivitas komunikasi massa, komunikasi dengan menggunakan media massa.

Dalam komunikasi massa, Film adalah salah satu hasil teknologi yang sering digunakan secara efektif. Film bisa membentuk masyarakat berdasarkan pesan di baliknya. Film juga mampu menjangkau audience dalam jumlah yang cukup banyak, dan mampu memasukkan pesan-pesan secara laten, sehingga dapat mempengaruhi audience tanpa terasa.

Film merupakan respon "penemuan" waktu luang di luar jam kerja dan jawaban terhadap kebutuhan dalam memenuhi unsur budaya. Jadi, ditinjau dari perkembangan Email: komunika@uhamka.ac.id fenomenalnya film memang berperan besar dalam dalam memenuhi kebutuhan yang tersembunyi (Wibowo, 2019). Dari hal ini kita mengetahui bahwa film merupakan salah satu jenis komunikasi massa yang efektif.

Film diciptakan berpangkal dari realitas masyarakat dan lingkungannya (Nurliyanti, et al, 2018). Sehingga film mempunyai kemampuan untuk merepresentasikan realitas dalam masyarakat dan memuat nilai budaya dalam pesan-pesan yang disampaikannya.

Film dan realitas masyarakat selalu berhubungan erat. Realitas dalam masyarakat adalah juga realitas yang kemudian terekam dalam film, begitupun dengan kritik atas sebuah perspektif. Film dan masyarakat adalah dua hal yang linier untuk dipahami. Film selalu merekam realitas yang tumbuh dan berkembang dalam masyarakat, lalu kemudian diproyeksikan ke atas layar (Irawanto, 1993).

Representasi sendiri berasal dari bahasa Inggris representation. Sementara dalam Kamus Besar bahasa Indonesia representasi berarti 
perbuatan mewakili, keadaan mewakili, apa yang mewakili, dan perwakilan (KBBI Daring). Representasi pada dasarnya ingin melihat bagaimana seseorang, kelompok, tindakan, kegiatan ditampilkan dalam teks (Eriyanto, 2001).

Ahli lain menyatakan bahwa representasi adalah bagaimana dunia ini dikonstruksi dan direpresentasikan secara sosial kepada dan oleh kita. Representasi dan makna budaya memiliki materialitas tertentu, mereka melekat pada bunyi, prasasti, obyek, citra, buku, majalah, dan program televisi. Mereka diproduksi, ditampilkan, digunakan dan dipahami dalam konteks sosial tertentu (Barker, 2000).

Dalam proses komunikasi, komunikator berusaha menyampaikan pesan kepada komunikan. Di dalam komunikasi dengan film, komunikator menyampaikan pesan dengan perantara lambang (simbol). Simbol memiliki makna karena simbol beroperasi dalam proses komunikasi tersebut. Dalam proses ini simbol yang digunakan terdiri atas 2 jenis yaitu simbol verbal (bahasa, tulisan) dan simbol non-verbal (gesture, warna, bentuk, dll).

Dalam film, tanda-tanda ikonis, yaitu tanda yang menggambarkan sesuatu seringkali digunakan untuk menyampaikan pesan tidak secara verbal. Tanda ikonis tersebut akan diterima secara berbeda oleh komunikan yang satu dengan komunikan yang lain. Perbedaan penerimaan ini disebabkan karena komunikan memiliki frame of reference (kerangka rujukan) dan field of experience (lapangan pengalaman) yang berbeda. Sehingga pemaknaan atas pesan dalam film seringkali membutuhkan sistem semiotika yang bisa membantu memahami pesan yang dibawa film.

Dalam semiotika, bahasa merupakan unsur utama. Bahasa tidak netral dan tidak sepenuhnya berada dalam kontrol kesadaran (Sobur, 2009). Bahasa menandakan bukan karena mengekspresikan pikiran ataupun menggambar realitas, namun lebih disebabkan mengkonstitusi subyek sebagai mahluk kultural, historis, dan geografis.

Semiotika dalam istilah Barthes disebut semiology, pada dasarnya hendak mempelajari bagaimana kemanusiaan (humanity) memaknai hal-hal (things). Memaknai (to sinify) dalam hal ini tidak bisa disamakan dengan mengkomunikasikan (to communicate). Memaknai berarti bahwa obyek-obyek tidak hanya membawa informasi, dalam hal mana obyek-obyek itu hendak berkomunikasi, tetapi juga mengkonstitusi sistem terstruktur dari tanda (Sobur, 2009).

Roland Barthes yang lahir tahun 1915 di Cherbourg dan dibesarkan di Bayonne, kota kecil dekat pantai Atlantik di sebelah barat daya Perancis berpendapat bahwa bahasa adalah sebuah sistem tanda yang mencerminkan asumsiasumsi dari suatu masyarakat tertentu dalam waktu tertentu. Dari pandangan Barthes ini kita bisa mengetahui bahwa bahasa yang berlaku dalam sebuah masyarakat bisa saja tidak berlaku dalam masyarakat yang lain, demikian pula bahasa yang berlaku pada waktu tertentu, bisa saja tidak berlaku lagi pada masa yang lain.

Dalam pengertian Barthes makna dibedakan menjadi dua, yaitu makna denotatif dan makna konotatif. Dalam pengertian umum makna denotative atau denotasi adalah makna harfiah, makna yang sesungguhnya. Proses signifikansi secara tradisional yang disebut sebagai denotasi ini biasanya mengacu pada penggunaan bahasa dengan arti yang sesuai dengan apa yang terucap, dan makna konotatif adalah bukan makna harfiah. Tetapi menurut Barthes, denotasi merupakan sistem signifikansi tingkat pertama, sementara konotasi merupakan sistem signifikansi tingkat kedua.

Budiman menyebutkan bahwa menurut kerangka Barthes, konotasi identik dengan operasi ideologi, yang disebutnya sebagai "mitos", dan berfungsi untuk mengungkapkan dan memberikan pembenaran bagi nilai-nilai dominan yang berlaku dalam suatu periode tertentu (Sobur, 2009). Dalam mitos terdapat pola tiga dimensi penanda, petanda, dan tanda, akan tetapi mitos dibangun oleh satu rantai pemaknaan yang telah ada sebelumnya atau dengan kata lain mitos adalah suatu sistem pemaknaan tataran kedua.

Semiotika bertujuan untuk menggali hakikat sistem tanda yang beranjak keluar kaidah tata bahasa, sintaksis, dan mengatur arti teks yang rumit, tersembunyi dan bergantung pada kebudayaan. Hal ini kemudian menimbulkan perhatian pada makna tambahan (connotative) dan arti penunjukan (denotative) atau kaitan dan 
kesan yang ditimbulkan dan diungkapkan melalui penggunaan dan kombinasi tanda (Sobur, 2012)

Sementara patriarki (patriarch) secara harfiah berarti kekuasaan bapak. Di Indonesia sendiri budaya patriarki masih menguasai banyak sendi kehidupan. Pada mulanya patriarki digunakan untuk menyebut satu jenis "keluarga yang dikuasai laki-laki", yaitu rumah tangga besar yang terdiri dari kaum perempuan, laki-laki muda, anak-anak, budak dan pelayan rumah tangga yang berada di bawah kekuasaan laki-laki (bapak). Istilah ini digunakan secara lebih umum untuk menyebut kekuasaan laki-laki (Bhasin, 1996).

Pinem menyebutkan bahwa patriarki juga dapat dijelaskan sebagai keadaan masyarakat yang menempatkan kedudukan dan posisi lakilaki lebih tinggi daripada perempuan dalam segala aspek kehidupan social, budaya, dan ekonomi (Aritonang, 2010).

Dengan adanya budaya patriarki, perempuan berada dalam kekuasaan laki-laki. Perempuan tidak bisa menyampaikan pendapat, pemikiran dan keinginannya secara terbuka. Komunikasi dan ruang geraknya seolah dibatasi dan hanya menjadi obyek dari semua keputusan dan pemikiran laki-laki.

Sementara itu bidang kehidupan perempuan yang berada dalam kontrol patriarki adalah 1) Daya produktif atau tenaga kerja perempuan, 2) Reproduksi perempuan, 3) Kontrol atas seksualitas perempuan, 4) Gerak perempuan, 5) Harta milik dan sumber daya ekonomi lainnya (Bhasin, 1996).

Film "Istri Orang" merupakan sebuah film karya Tumbuh Sinema Rakyat yang diproduksi dengan cara yang unik. Film ini diproduksi tanpa menggunakan teks skenario dan membiarkan para pemain yang merupakan warga asli lokasi pengambilan gambar mengeksplorasi dengan caranya sendiri untuk menyampaikan pesan.

Film "Istri Orang" bercerita tentang perempuan yang hidup dalam dunia yang dikuasai laki-laki. Endah, seorang remaja perempuan, pelajar SMA di Kepulauan Kangean yang terpencil, mulai menyukai lawan jenis. Ia menjalin hubungan dengan dengan seseorang yang berniat menjadikannya sebagai istrinya kelak. Akan tetapi ayah Endah justru menjodohkan Endah dengan seorang laki-laki yang berasal dari keluarga yang lebih kaya.
Perjodohan itu diatur oleh Ayah Endah dan calon mertuanya. Endah tidak kuasa menolak perjodohan. Ia merasa dijual oleh ayahnya sendiri, dan suaranya tak pernah didengarkan. Keinginannya untuk terus sekolah dan tidak buru-buru menikah jika harus berakhir menjadi janda tak pernah dipahami. Laki-laki yang dekat dengannya-pun tak pernah bisa mengerti keinginannya untuk menyelesaikan sekolah dan tidak buru-buru menikah, ia hanya peduli bahwa suatu ketika nanti Endah akan dijadikannya istri dan melahirkan anak-anaknya. Endah merasa sendirian dan tak ada yang bisa membelanya, karena ibunya, satu-satunya orang yang selalu membelanya, dan mungkin juga mengalami permasalahan yang sama sudah meninggal 3 tahun sebelumnya.

Hari pernikahannya pun tiba. Endah menikah dengan putra pemilik penggilingan padi, sawah, dan ternak di kampungnya. Setelah menikah, Endah menjadi ibu rumah tangga dan mengerjakan semua pekerjaan domestik di rumah mertuanya. Bahkan ia juga harus mengurus penggilingan padi dan ternak yang merupakan harta kekayaan mertuanya sementara suaminya hanya bersantai dan menikmati motor besarnya yang tak pernah merasakan jalanan aspal.

Suami Endah sadar bahwa Endah tak mencintainya, dan iapun tak mencintai Endah, sehingga ia tidak akan memaksa Endah untuk melayaninya. Ia justru pergi menjadi TKI ke Malaysia dan meninggalkan Endah yang seakan tak jelas statusnya. Ia masih seorang istri, tetapi ia seperti tak memiliki suami. Di tengah ketidakpastian, ia bertemu dengan laki-laki lain, seorang pengantar air. Mungkin hanya pertemuan biasa, tetapi bagi Endah yang biasa diabaikan dan tak didengarkan seolah oase.

Kedekatan itu memunculkan niat untuk kabur ke Malaysia bersama, tetapi Endah sebagai perempuan biasa di pulau terpencil, kemudian menyerah kepada keadaan dan memilih untuk tetap tinggal bersama segala permasalahan dan himpitan, dan membiarkan kekasihnya berangkat ke Malaysia sendiri.

Berlatar belakang sebuah pulau terpencil yang kering dan gersang, berbagai permasalahan, ditampilkan secara terbuka. Dalam film ini tergambar dunia yang sangat memuja nilai-nilai patriarki, perempuan hanya menjadi obyek. Semua keputusan dan peran yang harus 
ditanggung perempuan ditentukan seluruhnya oleh laki-laki, dan perempuan hanya menerima, tanpa ada peluang untuk memberontak.

Film ini pernah diputar dalam Jogja Asian Film Festival 2018, Fukuoka International Film Festival 2019, dan diputar secara independen. Film ini juga meraih penghargaan Naskah Terpuji Majalah Tempo 2019.

Dengan adanya realitas diatas, peneliti tertarik untuk menganalisis representasi budaya patriarki berupa kontrol laki-laki terhadap kehidupan perempuan yang ada dalam film Istri Orang. Bagaimana realitas ketimpangan gender yang begitu meminggirkan perempuan sebagai warga kelas 2 digambarkan dalam film ini.

\section{METODE PENELITIAN}

Penelitian ini menggunakan pendekatan kualitatif karena peneliti ingin mendapatkan gambaran yang jelas mengenai nilai-nilai patriarkal yang ada dalam film Istri Orang. Dengan pendekatan ini peneliti berharap dapat memahami, menjelaskan dan memperoleh gambaran yang luas dan mendalam mengenai masalah patriarki dalam film melalui tanda-tanda yang berupa gambar, dialog, dan musik yang dirangkai dalam scene menjadi pesan.

Metode yang digunakan adalah analisis semiotik. Semiotika pada dasarnya adalah ilmu tentang tanda. Tujuannya adalah untuk menunjukkan bagaimana terbentuknya tandatanda beserta kaidah-kaidah yang mengaturnya (Sobur, 2009).

Pendekatan semiotik yang digunakan adalah semiotika Roland Barthes dengan pertimbangan bahwa semiotik melihat media sebagai struktur secara keseluruhan, dan semiotik pada dasarnya bersifat kualitatif-interpretatif.

Adapun data yang dianalisis dalam penelitian ini berupa data primer yang diperoleh langsung melalui observasi obyek penelitian berupa film Istri Orang dalam format MP4. Sedangkan data sekunder didapatkan melalui studi pustaka dari buku, internet dan literatur lain yang mendukung data primer.

Secara fisik film dapat dipecah menjadi unsur-unsur berupa shot, adegan (scene) dan sekuen (sequence) (Himawan, 2008). Shot merupakan unsur terkecil dari film, sekumpulan shot kemudian terkumpul menjadi adegan (scene). Scene adalah satu segmen pendek dari keseluruhan cerita yang memperlihatkan aksi berkesinambungan yang diikat oleh ruang, waktu, isi (cerita), tema, karakter, atau motif. Sementara sekuen adalah satu segmen besar yang memperlihatkan satu rangkaian peristiwa yang utuh. Penelaahan scene merupakan hal yang paling memungkinkan untuk menganalisis film dengan komprehensif.

Sedangkan teknik pengumpulan data dalam penelitian ini menggunakan dua cara, yaitu observasi untuk mendalami obyek penelitian secara langsung dan memperoleh fakta terkait obyek. Analisa pada penelitian ini berfokus pada tanda dan makna dominasi laki-laki terhadap perempuan yang ada pada film Istri Orang. Metode semiotik ini mempunyai sifat kualitatif interpretatif yang berfokus pada tanda dan makna sebagai obyek kajian dan bagaimana peneliti menafsirkan dan memahami kode dalam tanda dan teks. Teknik berikutnya adalah dengan studi pustaka dari buku dan rujukan lain yang mendukung proses penafsiran tanda dan teks.

\section{HASIL DAN PEMBAHASAN}

Dalam film Istri Orang, peneliti menemukan banyak scene yang menggambarkan bagaimana patriarki ada dan mempengaruhi hidup Endah sebagai tokoh utama. Bidang kehidupan yang berada di bawah kontrol patriarki tergambar dalam film pada beberapa scene sebagai berikut:

\begin{tabular}{|l|l|}
\hline \multicolumn{1}{|c|}{$\begin{array}{c}\text { Bidang } \\
\text { kehidupan yang } \\
\text { Berada di } \\
\text { Bawah Kontrol } \\
\text { Patriarki }\end{array}$} & \multicolumn{1}{|c|}{ Scene } \\
\hline $\begin{array}{l}\text { Daya produkif } \\
\text { atau tenaga } \\
\text { kerja } \\
\text { perempuan }\end{array}$ & a) $\begin{array}{l}\text { Scene Endah } \\
\text { melakukan semua } \\
\text { pekerjaan domestik } \\
\text { di rumah mertuanya }\end{array}$ \\
& b) $\begin{array}{l}\text { Scene Endah bekerja } \\
\text { merawat ternak milik } \\
\text { mertuanya, suaminya } \\
\text { bersantai }\end{array}$ \\
& c) $\begin{array}{l}\text { Scene Endah bekerja } \\
\text { di penggilingan padi } \\
\text { milik mertuanya }\end{array}$ \\
\hline
\end{tabular}




\begin{tabular}{|c|c|c|}
\hline & d) & $\begin{array}{l}\text { Scene Endah bekerja } \\
\text { merawat ternak milik } \\
\text { mertuanya, } \\
\text { mertuanya hanya } \\
\text { mengawasi }\end{array}$ \\
\hline $\begin{array}{l}\text { Reproduksi } \\
\text { perempuan }\end{array}$ & a) & $\begin{array}{lr}\text { Scene } & \text { Endah } \\
\text { berbicara dengan } \\
\text { kekasihnya, ia tak } \\
\text { mau cepat-cepat } \\
\text { menikah }\end{array}$ \\
\hline $\begin{array}{l}\text { Kontrol atas } \\
\text { seksualitas } \\
\text { perempuan }\end{array}$ & a) & $\begin{array}{lr}\text { Scene } & \text { Endah } \\
\text { menunggu } & \text { suaminya } \\
\text { di kamar } & \end{array}$ \\
\hline $\begin{array}{l}\text { Gerak } \\
\text { perempuan }\end{array}$ & a) & $\begin{array}{l}\text { Scene Endah dirias } \\
\text { sebagai pengantin } \\
\text { kemudian di arak } \\
\text { diatas kuda hias }\end{array}$ \\
\hline & b) & $\begin{array}{l}\text { Scene Endah pulang } \\
\text { menumpang } \\
\text { pengantar air, } \\
\text { mertuanya menatap } \\
\text { dengan tatapan tidak } \\
\text { suka }\end{array}$ \\
\hline \multirow[t]{2}{*}{$\begin{array}{l}\text { Harta milik dan } \\
\text { sumber daya } \\
\text { ekonomi } \\
\text { lainnya }\end{array}$} & a) & $\begin{array}{l}\text { Scene } \\
\text { dimarahi mertuanya } \\
\text { karena mengajar di } \\
\text { sekolah, dianggap } \\
\text { tidak } \\
\text { menguntungkan } \\
\text { secara materi }\end{array}$ \\
\hline & b) & $\begin{array}{lr}\text { Scene } & \text { Endah, } \\
\text { kembali dimarahi } \\
\text { mertuanya karena } \\
\text { mengajar di sekolah, } \\
\text { dianggap tidak } \\
\text { menguntungkan } \\
\text { secara materi }\end{array}$ \\
\hline
\end{tabular}

Untuk menjelaskan bagaimana patriarki direpresentasikan dalam film Istri Orang, maka dari scene-scene yang telah dipilah akan dianalisis menggunakan pemaknaan aspek denotasi, konotasi, dan mitos. Konotasi mengungkapkan makna yang tersembunyi di balik tanda yang tersirat dalam sebuah hal. Denotasi menurut Berger yakni makna khusus yang terdapat dalam sebuah tanda dan pada intinya dapat disebut sebagai gambaran sebuah petanda (Sobur, 2003). Penelitian ini dapat dilihat dari potongan scene yang menjelaskan tentang bagaimana bidang kehidupan perempuan yang berada di bawah control patriarki tergambarkan dalam film ini.

1. Daya produktif atau tenaga kerja kerja perempuan

a) Scene Endah melakukan pekerjaan Domestik di rumah mertuanya.

Dalam scene tergambar Endah yang melakukan pekerjaan domestik di rumah mertuanya, mulai dari menyusun perabotan hingga menyapu lantai. Endah yang berpakaian kaos dengan sarung mengerjakan pekerjaannya dalam diam, tanpa ada yang mempedulikan.

Denotasi: Endah mengerjakan pekerjaan-pekerjaan domestik yang menjadi tanggung jawabnya setelah menjadi seorang istri, lokasi pekerjaan di dapur dan area belakang rumah. Pakaian yang dikenakan berupa kaos sederhana dan sarung.

Konotasi: setelah menjadi istri, maka Endah menjadi milik suami dan mertuanya. Ia harus mengerjakan semua pekerjaan domestik seperti halnya istri pada umumnya. Pakaiannya yang sederhana dan keberadaannya di dapur menandakan bahwa seorang istri tempatnya adalah di belakang, di dapur, dan tidak perlu untuk berpenampilan yang bagus karena ia hanya orang kedua dalam susunan perkawinan. Endah mengerjakan pekerjaan dalam diam bermakna bahwa ia tidak mempunyai suara atau pendapat yang seharusnya di dengarkan. Ia hanya mengerjakan apa yang seharusnya dikerjakan tanpa bisa menyatakan suaranya yang dibungkam lingkungan. Meskipun Endah bekerja dan melakukan semua pekerjaan rumah tangga, tetapi tidak ada penghargaan berupa materi yang diterima Endah 
sebagai istri, ia justru menjadi seperti pekerja di rumahnya sendiri.

Isu gender di ranah domestik dan publik mencakup: (a) Gender Stereotype (pelabelan negatif gender): perkasa-lemah-lembut; (b) Gender Norm: kepala keluarga-ibu rumah tangga; (c) Gender Role: pencari nafkah-pengelola rumah tangga; (d) Subordinasi: pemimpin-pihak yang dipimpin; (e) Marginalisasi: kalau terpaksa baru dimarginalkandiutamakan untuk dimarginalkan; (f) Burden (beban): mono burden-multi burden; (g) Violence (kekerasan): sebagian besar menjadi pelaku-sebagian besar menjadi korban kekerasan (Wibowo, 2011)

Masalah peran perempuan dalam ranah domestik merupakan masalah yang telah ada sejak lama, dan perempuan sebagai yang dinomor-duakan dalam susunan perkawinan seringkali harus menanggung beban untuk mengurus semua pekerjaan domestik tanpa adanya penghargaan dan bantuan dari anggota keluarga yang lain. Bahkan ketika perempuan memiliki peran ganda, perannya tak hanya di ranah domestik tetapi juga memiliki peran di ranah publik dengan bekerja misalnya, beban untuk berperan dalam semua urusan ranah domestik tidak kemudian berpindah atau berkurang, tetapi seringkali tetap menjadi beban bagi perempuan. Selain itu gender stereotype bahwa perempuan harusnya lemah lembut sehingga secara fisik cocok untuk mengerjakan pekerjaan domestik seakan melengkapi pemahaman bahwa tugas domestik hanya tugas perempuan. Dan perempuan seolah tidak mempunyai hak untuk menyuarakan pendapatnya, dan hanya menerima dalam diam.

b) Scene Endah merawat ternak milik mertuanya, sementara suaminya bersantai.
Denotasi: Endah memberi minum kerbau sementara suaminya hanya tiduran, bersantai mendengarkan musik sambil merokok. Endah menatap suaminya dengan tatapan tidak bahagia.

Konotasi: Kerbau, merupakan harta kekayaan yang sangat berharga bagi keluarga petani, maka harus dipelihara dengan baik. Pekerjaan pemeliharaan ternak ini, meskipun berat, tetapi karena berada di sekitar rumah, maka dianggap termasuk dalam pekerjaan domestik, sehingga menjadi tanggung jawab istri. Pembagian peran gender dilekatkan dengan dikotomi kerja publik-domestik, rasional-emosional, yaitu kerja-kerja di ruang publik kerap kali dilekatkan dengan kerja yang maskulin, dan kerja di ruang domestik dengan kerja yang feminine (Syaldi,2017).

Meskipun beban pekerjaan merawat ternak ini cukup berat karena harus mengangkat barang-barang berat, tetapi tanggung jawab diberikan sepenuhnya kepada pihak istri sebagai penanggung jawab pekerjaan domestik. Dan ini pekerjaan ini menjadikan daya produktif perempuan habis untuk melakukan pekerjaan domestik sementara laki-laki mempunyai berbagai privilege untuk tidak ikut mengerjakan tugas ini.

Pandangan Endah kepada suaminya yang bahkan tidak menganggapnya ada menjadi tanda kebencian pada sistem yang menjadikan perempuan sebagai pekerja di dalam rumahnya sendiri. Tanpa penghargaan materi, semua kewajiban pekerjaan rumah tangga dan tambahan pekerjaan merawat asset menjadikan perempuan menjadi tenaga kerja tak dibayar dalam rumah tangganya.

c) Scene Endah bekerja di penggilingan padi milik mertuanya

Endah bekerja keras di penggilingan padi milik mertuanya, sendirian. Ia 
bahkan mengangkat gabah dalam karung yang cukup berat.

Konotasi: Endah mengangkat karung berisi gabah yang begitu berat, hingga ia tidak kuat mengangkatnya sendiri. Penggilingan padi terletak di dekat rumah mertua Endah.

Denotasi: Melekatnya peran perempuan sebagai pekerja domestik sudah sejak lama terjadi. Perempuan sudah lama dilekatkan sebagai homemaker (pekerja domestik) yang tidak menghasilkan uang. Padahal dalam kenyataan, seringkali perempuan bisa mengambil peran ganda, bekerja di luar rumah yang menghasilkan uang dan juga melakukan pekerjaan domestik.

Yang terjadi, peran perempuan meskipun ia melakukan pekerjaan di dalam ranah domestik, ia sebetulnya mampu menghasilkan, seperti juga yang tergambar dalam scene, Endah mengurus penggilingan padi milik mertuanya, yang seharusnya menghasilkan uang. Tetapi dalam kenyataannya, pekerjaan yang masih berada di wilayah rumah meskipun menghasilkan uang tidak dianggap sebagai pekerjaan yang bernilai ekonomis, semua dilakukan dengan dasar perannya sebagai istri menyelesaikan atau membantu pekerjaan suami, tanpa bayaran. Sehingga dalam hal ini perempuan menjadi tenaga kerja yang bisa dimanfaatkan tanpa bayaran.

Beratnya gabah dalam karung yang harus diangkat oleh Endah selama bekerja di penggilingan padi milik mertuanya seperti halnya beratnya beban pekerjaan yang harus ditanggungnya di dalam rumah tangganya. Meskipun harus bekerja keras dan berat, tetapi Endah sebagai perempuan tidak mendapatkan penghargaan semestinya dari keluarga dan lingkunganya. Ia diperlakukan seperti pekerja.
Beratnya gabah dalam karung yang harus diangkat oleh Endah juga menyimbolkan beratnya beban ganda yang harus ditanggung oleh Endah dan perempuan-perempuan lainnya yang tidak bisa menentukan nasibnya sendiri.

d) Scene Endah merawat ternak sementara mertuanya hanya mengawasi

Endah bekerja memberi minum kerbau milik keluarga mertuanya, sementara mertuanya hanya duduk mengawasi sambil merokok.

Denotasi: Endah bekerja memberi minum kerbau milik mertuanya. Sementara mertuanya hanya mengawasi dari jauh sambil merokok.

Konotasi: Perempuan yang harus mengerjakan pekerjaan domestik dan juga mengurus ternak keluarga, tak lepas dari pengawasan berbagai pihak.

Perempuan yang melakukan berbagai pekerjaan yang seharusnya bisa menghasilkan materi, pada kenyataannya karena pekerjaan tersebut berlokasi di rumah justru kemudian dikategorikan menjadi pekerjaan domestik yang merupakan pekerjaan "wajib" bagi perempuan dan tidak menghasilkan materi. Perempuan menjadi pekerja yang tidak dibayar untuk melakukan pekerjaan yang berat sekalipun. Pelekatan pekerjaan ini bahkan tidak cuma dilekatkan oleh suami, tetapi juga oleh keluarga besar yang turut mengawasi.

Seakan tidak ada ruang bagi perempuan untuk melepaskan diri dari berbagai kewajiban pekerjaan domestik karena semua anggota keluarga termasuk mertuanya yang seorang laki-laki akan selalu mengawasi dan siap menilai pekerjaan yang dilakukannya.

Pekerjaan yang dilakukan oleh Endah sebagai perempuan seperti sudah tertanam dalam masyarakat, sehingga anggota masyarakat lain seperti tidak memiliki kepedulian dan justru menjadi pengawas yang memastikan perempuan 
mengerjakan hal tersebut sesuai dengan tradisi yang telah mendarah daging meskipun dikerjakan dengan penuh keterpaksaan.

2. Reproduksi perempuan

a) Scene Endah berbicara dengan kekasihnya, menyatakan ia tak mau cepat-cepat menikah yang akhirnya nanti hanya menjadi janda dan lebih buruk lagi punya anak yang nantinya jadi pemabuk, tapi kekasih Endah tidak mau mengerti dengan pemikiran Endah Denotasi: Endah mengatakan tidak mau cepat-cepat menikah dan kemudian menjadi janda dengan anak yang akan jadi pemabuk, tetapi kekasih Endah mengatakan tetap akan menikahi Endah.

Konotasi: perempuan dianggap tidak merdeka dan bisa menentukan reproduksinya sendiri. Perempuan hanya pihak yang dianggap mempunyai sistem reproduksi tetapi tidak memiliki hak untuk mengontrol reproduksinya sendiri.

Dalam Suara APIK disebutkan bahwa kesehatan reproduksi adalah keadaan kesejahteraan fisik, mental, dan sosial yang utuh, dan bukan hanya tidak adanya penyakit atau kelemahan, dalam segala yang berhubungan dengan sistem reproduksi dan fungsi serta proses-prosesnya. Oleh karena itu, kesehatan reproduksi berarti bahwa orang dapat mempunyai kehidupan seks yang memuaskan dan aman, dan bahwa mereka memiliki kemampuan untuk bereproduksi dan kebebasan untuk menentukan apakah mereka ingin melakukannya, bilamana, dan berapa seringkah. Kesehatan reproduksi juga mencakup kesehatan seksual, yang bertujuan meningkatkan status kehidupan dan hubungan-hubungan perorangan, dan bukan semata-mata konsultasi dan perawatan yang bertalian dengan reproduksi dan penyakit yang ditularkan melalui hubungan seks (Munti, 2006).

Kontrol atas sistem reprodukssi seharusnya berada di tangan perempuan sebagai pemilik sistem dan tubuh, ia seharusnya memiliki kebebasan untuk menentukan apakah ia ingin melakukannya, bilamana dan berapa sering. Tetapi dalam kenyataannya seperti tergambar dalam film, reproduksi tetap ditentukan oleh lakilaki yang tidak mau mengerti apa yang diinginkan perempuan, semata untuk memuaskan keinginan laki-laki.

Laki-laki cenderung tidak peduli dengan hal lain, hanya memikirkan jika waktunya tiba, perempuan akan dijadikannya istri dan kemudian melahirkan anak-anaknya. Hanya dipandang sebagai seseorang yang memiliki alat reproduksi tetapi tidak bisa menentukan apa yang akan dilakukannya dengan alat reproduksi tersebut.

3. Kontrol atas seksualitas perempuan

a) Scene Endah menunggu suaminya di kamar

Konotasi: Endah berdandan menunggu suaminya masuk kamar. Endah berbaring berharap diperlakukan seperti istri lain. Tetapi suaminya justru memakaikan kerudungnya

Denotasi: Dalam hal seksualitas, perempuan merupakan pihak yang hanya menunggu inisiatif dari laki-laki. Ia hanya menunggu apa yang akan dilakukan oleh pasangannya terhadap dirinya tanpa bisa menyatakan pendapatnya. Bahkan ketika laki-laki yang menjadi suaminya menolaknya, perempuan tetap harus berdiam diri tanpa bisa mengungkapkan apa yang ada di dalam pikiran dan perasaannya. Perempuan hanya bisa menerima perlakuan pasangannya tanpa bisa mengungkapkan keinginan atas seksualitasnya. 
Kontrol atas tubuh dan seksualitas perempuan seharusnya otonom, mereka bisa menjadi obyek maupun subyek seperti halnya laki-laki. Sementara budaya yang dianut sebagian besar masyarakat kita adalah budaya patriarkat yang menempatkan laki-laki lebih tinggi. Budaya ini didasarkan pada suatu pandangan yang mengangap bahwa norma laki-laki yang menjadi pusat (center) dari relasi-relasi sosial yang ada (Ida, 2005).

Sehingga dalam hal ini perempuan menjadi pihak yang hanya bisa menerima perlakuan dari laki-laki, menerima yang akan terjadi tanpa bisa mengungkapkan apa yang diinginkan atau tak diinginkannya.

Dalam hal ini seksualitas perempuan adalah sebagai konstruksi sosial dimana dalam situasi ini cara pandang seseorang menilai seksualitasnya sangat ditentukan oleh nilai-nilai budaya yang melingkupinya.

4. Gerak perempuan

a) Scene Endah yang didandani sebagai pengantin kemudian di arak diatas kuda hias

Denotasi: Ketika menikah Endah didandani dan harus melakukan arakarakan dengan menaiki kuda yang juga di dandani. Prosesi arak-arakan dipimpin oleh ayah Endah dan mertuanya.

Konotasi: Dalam prosesi arak-arakan ketika menikah, Endah didandani, seperti juga kuda yang dinaikinya, menggambarkan bahwa Endah seperti juga kuda yang dimiliki orang lain dan harus menurut apa kata tuannya. Di arak artinya dipertontonkan, dan perlakuan ini bermakna perempuan hanya seperti barang milik laki-laki yang bisa diperlakukan seperti kemauan pemilik. Perempuan dalam prosesi ini hanya menuruti apa yang diperintahkan kepadanya, dihias, kemudian dipertontonkan, dan semua gerak geriknya diawasi.

Otonomi atas tubuh, adalah upaya sistematis berkelanjutan dari setiap perempuan untuk mau dan mampu menjadikan tubuhnya sendiri otonom, utuh dari penjajahan siapa, dan pihak manapun dan dimata siapapun (Harper, 2000).

Dalam hal ini, perempuan tidak mempunyai otonomi bahkan untuk tubuhnya sendiri. Ketika ia dirias dan kemudian dipertontonkan kepada orang lain, seperti halnya kuda yang juga di hias, maka kontrol atas tubuhnya sendiri hilang. Ia hanya menjadi pajangan, benda, yang bisa dimiliki dan diperlakukan bagaimanapun oleh pemilik.

Pemimpin arak-arakan yang tergambar adalah laki-laki (ayah Endah dan mertuanya) berarti bahwa dalam setiap peristiwa penting (seperti halnya pernikahan) laki-laki adalah pemimpin, yang mengambil keputusan dan menentukan, bahkan keputusan pada otonomi tubuh perempuan.

b) Scene Endah pulang menumpang pengantar air dan mertuanya menatapnya dengan tatapan tidak suka

Denotasi: Endah pulang dari mengajar di sekolah. Ia pulang dengan menumpang gerobak pengantar air, mertua menatapnya curiga dan tidak suka.

Konotasi: Perempuan tidak memiliki kebebasan seperti halnya laki-laki. Gerak dan perilakunya dibatasi oleh lingkungan sekelilingnya. Ia tidak bebas melakukan apa yang diinginkan, seolah semua mengawasi apa yang dilakukannya dan siap untuk mengingatkan atau menghukum bila ia melakukan apa yang tidak sesuai dengan nilai dan norma yang merupakan konstruksi laki-laki.

Untuk mengontrol produktivitas, reproduksi, dan seksualitas perempuan, 
laki-laki merasa perlu untuk membatasi gerak perempuan. Perempuan begitu dibatasi dengan adanya pembatasan untuk meninggalkan rumah tangga, pembatasan interaksi antara kedua jenis kelamin dan sebagainya. Dan hal ini sangat spesifik gender karena tidak berlaku untuk laki-laki yang tidak mengalami pembatasan yang sama.

5. Harta milik dan sumber daya ekonomi lainnya

a) Scene Endah yang dimarahi mertuanya karena mengajar di sekolah yang dianggap tidak menguntungkan secara materi

Denotasi: Endah dimarahi setelah pulang bekerja di sekolah.

Konotasi: Perempuan tidak memiliki banyak pilihan dalam menentukan sumber daya ekonomi yang ingin dijalaninya. Sebagai perempuan yang apalagi sudah menikah, maka tanggung jawab terbesarnya adalah pekerjaan domestik, termasuk di dalamnya adalah mengurus harta benda keluarga suami.

Sebagian besar hak milik dan sumber daya produktif lain dikontrol oleh lakilaki. Begitupun dengan pilihan sumber daya apa yang ingin digunakan perempuan untuk mencapai yang diinginkan. Begitupun dengan harta milik, seringkali meskipun dalam kenyataannya perempuan diberi beban untuk bekerja dan memelihara harta milik keluarga, tetapi ketika harta milik itu menghasilkan nilai ekonomi, secara ekonomi akan menjadi milik laki-laki.

b) Scene Endah yang kembali dimarahi mertuanya karena mengajar di sekolah yang dianggap tidak menguntungkan secara materi

Denotasi: Endah dimarahi bapak mertuanya karena mengajar di sekolah.

Konotasi: pilihan perempuan untuk menentukan sumber daya ekonomi yang ingin dijalaninya tidak terakomodir.
Di sini tergambar dengan jelas bagaimana harta milik dan sumber daya lainnya tetap menjadi milik laki-laki, diatur oleh laki-laki dan perempuan harus ikut berperan memelihara dan merawat tanpa bisa memiliki harta tersebut. Dalam hal ini hak memiliki dan menentukan apa yang dipilihnya untuk mencapai sumber daya ekonomi tersebut seluruhnya dikuasai laki-laki.

\section{Kesimpulan}

Patriarki tergambar dengan jelas dalam film Istri Orang. Berdasarkan analisa, patriarki dalam film Istri Orang tergambar melalui kategori-kategori bidang kehidupan yang berada di bawah kontrol patriarki.

Dalam hal daya produktif atau tenaga kerja perempuan, perempuan masih didominasi laki-laki yang menuntutnya melakukan pekerjaan domesti. Bahkan ketika pekerjaan domestik itu sebetulnya adalah pekerjaan yang menghasilkan nilai ekonomi, tetap diperhitungkan sebagai pekerjaan domestik yang tidak menghasilkan, sehingga perempuan justru seperti menjadi pekerja di rumahnya sendiri.

Dalam bidang reproduksi perempuan, perempuan yang memiliki tubuh dan sistem reproduksi justru tidak mempunyai kebebasan untuk menentukan apa yang diinginkan atas system reproduksinya. Laki-laki masih menjadi pihak yang memegang kontrol mengenai kapan, bagaimana dan seberapa sering perempuan menginginkan system reproduksinya bekerja.

Seksuailitas perempuan juga merupakan bidang yang masih dikuasai laki-laki. Karena secara kultural, perempuan dibentuk dalam paham patriarki yang menyebabkannya hanya menerima perlakuan seksual dari laki-laki tanpa bisa menyuarakan apa keinginannya. Perempuan dalam posisi menunggu, dan tidak boleh menolak. Dan jika ditolak perempuan hanya diam.

Demikian juga dengan gerak perempuan. Semua gerakan perempuan dibatasi. Otonomi atas tubuhnya masih menjadi milik laki-laki, sehingga perlakuan dan gerakannya terbatas. Pembatasan dilakukan dengan membatasi untuk meninggalkan rumah tangga dan interaksi antara kedua jenis kelamin. 
Dan untuk harta milik dan sumber daya ekonomi lainnya, perempuan tidak memiliki pilihan untuk menentukan jalan sumber daya ekonomi apa yang akan digunakannya untuk memenuhi keinginannya. Semua ditentukan oleh laki-laki.

\section{Acknowledgment}

Terima kasih untuk Mas Dirmawan Hatta, sutradara dan penulis naskah Film Istri Orang yang telah memberi keleluasaan untuk meneliti film, dukungan data, dan waktu luang untuk wawancara selama penelitian.

\section{References}

Aritonang, Juneris. 2010. Hubungan Budaya Patriarki Terhadap Keputusan WUS Menjadi Akseptor Keluarga Berencana Di Lingkungan VI Simang Selayang Medan Tuntung 2010. Fakultas Keperawatan Universitas Sumatra Utara. Medan

Bahsin, Kamla. 2016. Menggugat Patriarki. Yayasan Bentang Budaya. Yogyakarta.

Barker, Chris. 2004. Cultural Studies, Teori dan Praktek. Sage Publication. London.

Eriyanto. 2001. Analisis Wacana, Pengantar Analisis Teks Media. LKiS Yogyakarta. Yogyakarta. https://kbbi.kemdikbud.go.id/entri/representasi

https://www.jurnalperempuan.org/wartafeminis/syaldi-sahude-kerja-kerjadomestik-adalah-tanggung-jawab-laki-lakidan-perempuan

Munti, Ratna Batara. 2006. Kesehatan Reproduksi Perempuan dan Pentingnya Amandemen UU Kesehatan. Swara APIK Edisi 32. Jakarta: LBH APIK.

Nurliyanti, Sri. Rande, Santi \& Qamara, Aji Eka. Representasi Budaya Patriarki Dalam Film Tenggelamnya Kapal Van Der Wijk. eJournal Ilmu Komunikasi. Volume 6, Nomor 3, 2018 219-305

Pratista, Himawan. 2008. Memahami Film. Homerian Pustaka. Yogyakarta

Sobur, Alex. 2009. Semiotika Komunikasi. PT Remaja Rosdakarya. Bandung.

Sobur, Alex. 2013. Analisis Teks Media. PT Remaja Rosdakarya. Bandung.

Wibowo, Ganjar. 2019. Representasi Perempuan dalam Film Siti. Nyimak Journal of Communication. Vol 3 No 1 : 47-59 ISSN 2580-3808.

Wandi, Gusri. 2015. Rekonstruksi Maskulinitas : Menguak Peran Laki-Laki Dalam Perjuangan Kesetaraan Gender. Kafa'ah : Kajian Gender Vol 5. No.2. Padang 